\title{
A Study on the Students' Reading Comprehension at the First Semester of Management Program at Islamic University of Indragiri \\ Tembilahan
}

\author{
Maizarah \\ maizarah_nurzainal@yahoo.com \\ Pendidikan Bahasa Inggris-FKIP \\ Islamic University of Indragiri - Tembilahan
}

\begin{abstract}
The problem in this study was the students' reading comprehension on the first semester of Management Program at Islamic University of Indragiri Tembilahan. This research only used one variable was reading comprehension. The research method used in this study was a descriptive research. The purpose of this study was to know the students' reading comprehension on the first semester of Management program at Islamic University of Indragiri Tembilahan. The total of the population used in this study were 163 students, the technique was used to take the sample is random sampling, the sample of this study was $25 \%$ from the population were 41 students. In collecting the data, the researcher used a reading test. After the data has been collected, the result of test shows that the students' reading comprehension was categorized as Average to Good because 59,39 in range 51-75, it is mean that the students should be improve their reading comprehension to be better than it.
\end{abstract}

Key words: Reading Comprehension, Descriptive Research

\section{INTRODUCTION}

English is an important language in the world. It is used around the world as communication by most of people. English has been taught in elementary school until the university level. It can be concluded that English have become the important subject in education. The students of Management Program also must be aware the important of English subject. Because, the information that is circulated in this world is mostly published in English. Many books are published in English. No matter who publishes it, which is sure to acquire a wide market many publishers publish reading in English. Major magazines such as Newsweek, Time, Vogue, Bazaar, People, Life, National Geographic, Mac World, etc. are written and published in English. In order to face the global business competition the businessman must have the ability to speak and understand reading texts in English. So, the students must have the ability to comprehend the reading text about business to face the global business competition.

McKinlay in https://www.ecsscotland.co.uk/news/why-is-it-important-tolearn-business-english/ stated that in the 21 st century we live in a truly global society, where communication with almost every part of the world is possible. The spread of English as the language of international business has made it more 
important than ever for people working with colleagues, clients and partners from other countries to understand each other, so that they can form effective and productive working relationships. In order to meet the demands of modern employers, everyone from university graduates to senior managers must be able use English for work.

Based on the preliminary observation done on November 2017 at the first students in Management Program in Islamic University of Indragiri Tembilahan was found that the students have the difficulties to comprehend a reading text even it is related to their vocation is business. They did not understand even the simple sentence. They felt so difficulty to connect one word to another word, one sentence to another sentence, and one paragraph to another paragraph.

Based on the explanation and problems mentioned above, it is necessary to conduct a research entitled "A Study on the Students' Reading Comprehension at the First Semester of Management Program at Islamic University of Indragiri Tembilahan".

Objective and Research Questions: The main objective of the research was to find out the students' reading difficulties o EFL Learners. The objective were as follows:

- To investigate the students' reading comprehension at the first Semester of Management Program at Islamic University of Indragiri Tembilahan

\section{LITERATURE REVIEW}

\section{The Nature of Reading}

Westwood (2008:32) states reading comprehension can be defined as an active thinking process which a reader intentionally constructs meaning to form a deeper understanding of concepts and information presented in a text. To comprehend, readers must use information they already possess to filter, interpret, organize and reflect upon the incoming information from the page. Efficient interpretation of text involves a combination of word recognition skills, linking of new information to prior knowledge, and application of appropriate strategies such as locating the main idea, making connections, questioning, inferring and predicting.

Moreover, Woolley (2011:15) defines reading comprehension as the process of making meaning from text. The goal, therefore, is to gain an overall understanding of what is described in the text rather than to obtain meaning from isolated words or sentences. In addition, Snow (2002: xiii) defines reading as the process of simultaneously extracting and constructing meaning through interaction and involvement with written language. It consists of three elements: the reader, the text, and the activity or purpose for reading.

In conclusion, reading comprehension is ability to read the text, process it, and understand its meaning. It means when one reads a text they should interpret the meaning of words and find the information from the text. 


\section{The Component of Reading Comprehension}

King and Stanley (2004:8) explain that there are five aspects in processing reading comprehension. They are; finding factual information, finding main idea, finding the meaning of vocabulary context, identifying reference, and making reference

The theory above can be described as follows:

1. Finding factual information

Factual information requires readers to scan specific details. there are many types of question of factual information such as question type reason, purpose, result, comparison, means, identify, time and amount in which most of the answer can be found in the text.

2. Finding main idea

Recognition of the main idea of a paragraph is very important because it is not only to understand the paragraph on the first reading, but also helps students remember the content later. The main idea of paragraph is what the paragraph develops.

3. Finding the meaning of vocabulary in context

Vocabulary is more that list of target language words. Vocabulary includes the right and appropriate used of the word. It means that the larger vocabulary the smaller misunderstanding. So, by knowing the meaning of the vocabulary the readers can achieve reading comprehension well.

4. Identifying references

Recognizing references words and being able to identify the word to which they refer to will help the reader understand the reader passage. Students of English might learn many rules for the sentence. Reference words are usually short and are very frequently pronouns, such as; it, she, he, they, this etc.

5. Making inference

Inference is a skill where the readers have to be able to read between lines, King and Stanley divide into two main attentions, draw logical inference and make accurate prediction.

\section{RESEARCH METHOD}

This research is descriptive research. Gay (2000:275) stated that "descriptive study determines and describes the way things are. The total population used in this study were 163 students, the technique was used to take the sample is random sampling, the sample of this study was $25 \%$ from the population were 41 students of the first semester of Management Program at Islamic University of Indragiri Tembilahan. The technique used to collect the data was a reading test. It consists of 20 questions was made based on the reading comprehension indicators were 1) Finding Main Idea, 2) Finding Factual Information, 3) Guessing meaning of vocabulary in text., 4) Identifying Reference, and 5) Making Inference. The data were analyzed using SPSS (Statistical Package for the Social Sciences). 
Table 1. The Classification of Students' Reading Comprehension

\begin{tabular}{|c|c|}
\hline The classification & Categories score \\
\hline $76-100$ & Good to excellent \\
\hline $51-75$ & Average to good \\
\hline $26-50$ & Poor to average \\
\hline $0-25$ & Poor \\
\hline
\end{tabular}

\section{FINDINGS AND DISCUSSION}

Table 2 shows that the mean of the students' reading comprehension was 59,39, it was categorized as Average to Good because 59,39 in range 51-75. The descriptions of the data are as follows:

Table 2. The Results of Students' Reading Comprehension Scores

\begin{tabular}{|c|c|c|}
\hline No. & Students & Score \\
\hline 1 & Student 1 & 75 \\
\hline 2 & Student 2 & 70 \\
\hline 3 & Student 3 & 85 \\
\hline 4 & Student 4 & 65 \\
\hline 5 & Student 5 & 55 \\
\hline 6 & Student 6 & 75 \\
\hline 7 & Student 7 & 70 \\
\hline 8 & Student 8 & 70 \\
\hline 9 & Student 9 & 70 \\
\hline 10 & Student 10 & 80 \\
\hline 11 & Student 11 & 80 \\
\hline 12 & Student 12 & 75 \\
\hline 13 & Student 13 & 25 \\
\hline 14 & Student 14 & 35 \\
\hline 15 & Student 15 & 45 \\
\hline 16 & Student 16 & 85 \\
\hline
\end{tabular}




\begin{tabular}{|c|c|c|}
\hline 17 & Student 17 & 50 \\
\hline 18 & Student 18 & 75 \\
\hline 19 & Student 19 & 55 \\
\hline 20 & Student 20 & 45 \\
\hline 21 & Student 21 & 50 \\
\hline 22 & Student 22 & 75 \\
\hline 23 & Student 23 & 80 \\
\hline 24 & Student 24 & 25 \\
\hline 25 & Student 25 & 75 \\
\hline 26 & Student 26 & 25 \\
\hline 27 & Student 27 & 60 \\
\hline 28 & Student 28 & 50 \\
\hline 29 & Student 29 & 30 \\
\hline 30 & Student 30 & 60 \\
\hline 31 & Student 31 & 45 \\
\hline 32 & Student 32 & 50 \\
\hline 33 & Student 33 & 30 \\
\hline 34 & Student 34 & 60 \\
\hline 35 & Student 35 & 60 \\
\hline 36 & Student 36 & 60 \\
\hline 37 & Student 37 & 55 \\
\hline 38 & Student 38 & 65 \\
\hline 39 & Student 39 & 65 \\
\hline 40 & Student 40 & 60 \\
\hline 41 & Student 41 & 70 \\
\hline \multicolumn{2}{|r|}{ Total } & 2435 \\
\hline & Mean & 59,39 \\
\hline
\end{tabular}


Table 3 clear that the frequency of interval 25.00 is 3 students $(7.3 \%)$, the frequency of interval 30.00 is 2 students (4.9\%), the frequency of interval 35.00 is 1 student $(2.4 \%)$, the frequency of interval 45.00 is 3 students $(7.3 \%)$, the frequency of interval 50.00 is 4 students $(9.8 \%)$, the frequency of interval 55.00 is 3 students (7.3\%), the frequency of interval 60.00 is 6 students $(14.6 \%)$, the frequency of interval 65.00 is 3 students (7.3\%), the frequency of interval 70.00 is 5 students $(12.2 \%)$, the frequency of interval 75.00 is 6 students $(14.6 \%)$, the frequency of interval 80.00 is 3 students (7.3\%), the frequency of interval 85.00 is 2 students $(4.9 \%)$.

Table 3.

The Frequency Distribution of Students' Reading Comprehension

\begin{tabular}{cccccc}
\hline No. & Score & Frequency & Percentage & $\begin{array}{c}\text { Valid } \\
\text { Percentage }\end{array}$ & $\begin{array}{c}\text { Cumulative } \\
\text { Percentage }\end{array}$ \\
\hline 1. & 25,00 & 3 & 6,8 & 7,3 & 7,3 \\
\hline 2. & 30,00 & 2 & 4,5 & 4,9 & 12,2 \\
\hline 3. & 35,00 & 1 & 2,3 & 2,4 & 14,6 \\
\hline 4. & 45,00 & 3 & 6,8 & 7,3 & 22,0 \\
\hline 5. & 50,00 & 4 & 9,1 & 9,8 & 31,7 \\
\hline 6. & 55,00 & 3 & 6,8 & 7,3 & 39,0 \\
\hline 7. & 60,00 & 6 & 13,6 & 14,6 & 53,7 \\
\hline 8. & 65,00 & 3 & 6,8 & 7,3 & 61,0 \\
\hline 9. & 70,00 & 5 & 11,4 & 12,2 & 73,2 \\
\hline 10. & 75,00 & 6 & 13,6 & 14,6 & 87,8 \\
\hline 11. & 80,00 & 3 & 6,8 & 7,3 & 95,1 \\
\hline 12. & 85,00 & 2 & 4,5 & 4,9 & 100,0 \\
\hline & Total & 41 & 93,2 & 100,0 & \\
\hline & Missing & 3 & 6,8 & & \\
\hline & System & & 100,0 & & \\
\hline
\end{tabular}

More detailed information about the students' reading comprehension is presented in the following histogram: 


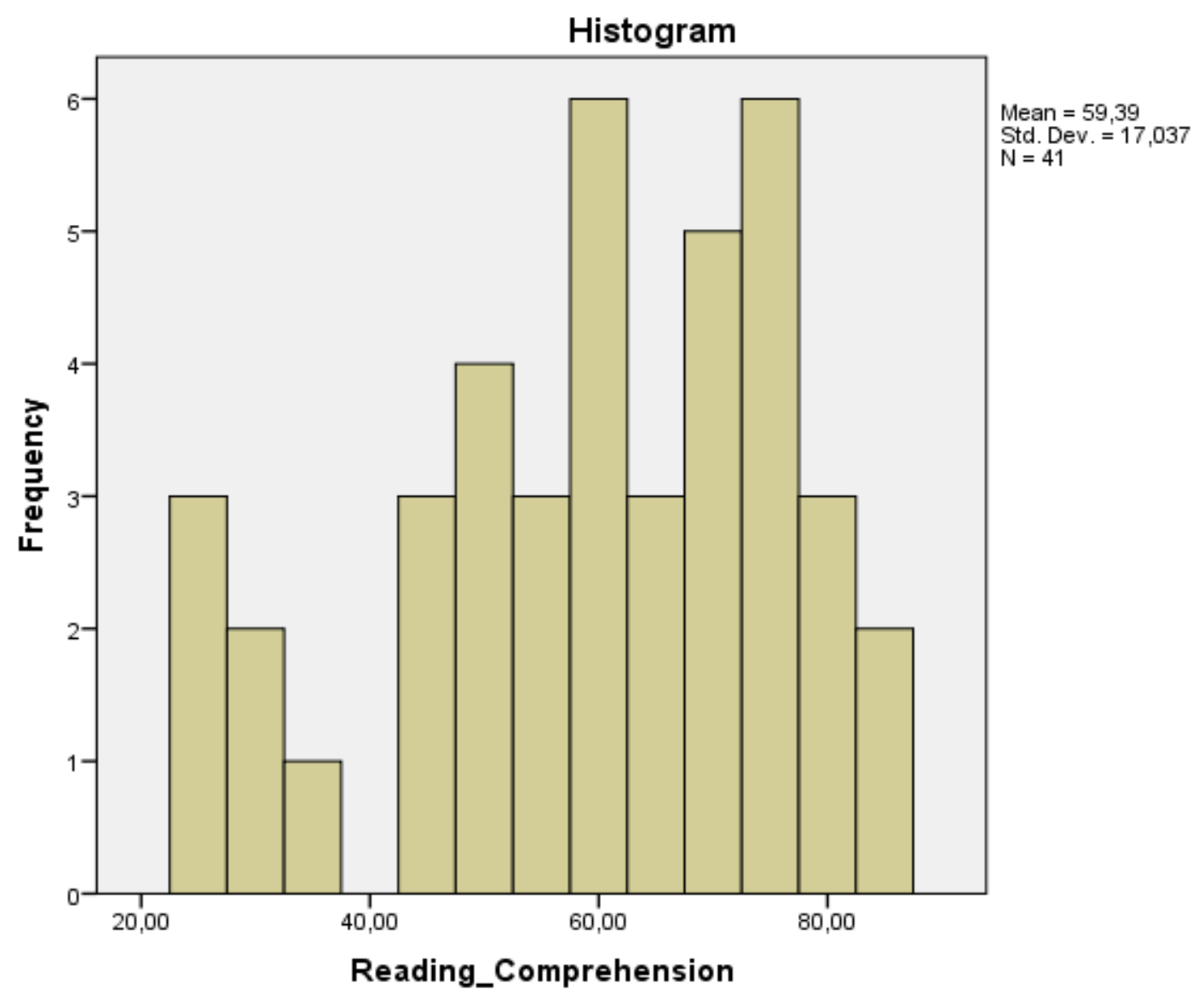

Table 4 demonstrates that there are 4 categories of the students' reading comprehension. The frequency of Good to Excellent category is 5 students (12.19\%), the frequency of Average to Good is 23 students (56.10\%), the frequency of Poor to Average category is 10 students (24.39\%), the frequency of Poor category is 3 students $(7,32 \%)$. Thus, the majority of the students' reading comprehension was classified into Average to Good category.

Table 4.

The Classification of Students' Reading Comprehension

\begin{tabular}{|c|c|c|c|c|}
\hline No & Category & Score & Frequency & Percentage $(\%)$ \\
\hline 1. & Good to excellent & $76-100$ & 5 & 12.19 \\
\hline 2. & Average to good & $51-75$ & 23 & 56.10 \\
\hline 3. & Poor to average & $26-50$ & 10 & 24.39 \\
\hline 4. & Poor & $0-25$ & 3 & 7.32 \\
\hline \multicolumn{3}{|c|}{ Total } & 41 & 100 \\
\hline
\end{tabular}




\section{DISCUSSION}

The main objective of this research was to find out the students' reading comprehension at the first semester of Management Program at Islamic University of Indragiri Tembilahan. In this research the researcher gave a reading test to collect the data of students' reading comprehension. The result of test shows that the students' reading comprehension was cateorized as Average to Good because 59,39 in range $51-75$, it is mean that the students should be improve their reading comprehension to be better than it.

As a result the students stilll have enough reading comprehesion, it can be btetter. As the solution for their problem to improve their reading comprehesnion is they must have good reading strategy, improve the vocabulary, and read a reading text as many as possible. The students of management faculty should have the ability to read and understand the text of English bcecause it will be used in their carrier in the future to face the globalization era.

\section{CONCLUSION}

Based on the finding and discussion, it could be concluded that the students' reading comprehension must be improve to be better than now. The students must practice more to read an English text especially text about business, moreover they must memorize vocabulary at least one word one day.

\section{REFERENCES}

Gay, L.R and Airasian, Peter. 2000. Educational research. Saddle river: New Jersey.

Harris, David P. 1969. Testing English as a Second Language. New York: Me Graw Hill Company

King. C, and Stanley, N. 2004. Insight and Strategies for Teaching Reading. Sidney: Harcourt Brace Javanovich Group.

McKinlay, Laura. https://www.ecsscotland.co.uk/news/why-is-it-important-tolearn-business-english/

Snow, Katherine. 2002. Reading for Understanding toward and $R \& D$ Program in Reading Comprehension. RAND.

Westwood, Peter. (2008). What teachers need to know about reading and writing difficulties. Camberwell: Australian Council for Educational Research Ltd (ACER Press)

Woolley, G. 2011. Reading Comprehension: Assisting Children with Learning Difficulties, DOI 10.1007/978-94-007-1174-7_2, Springer Science +Business Media B.V. 